\title{
Conclusion to Part 2
}

We have two possible strategies in the Southern Africa conflict. One matches our current policy: to wait and see, placate, lie low, limit damages as far as possible, cede only under the pressure of events. Apparently, people think that this policy allows us to come off best and that it corresponds with public opinion. The other possibility is an Africa policy worthy of its name, that takes our long-term interests into account and does not push us into the camp of the white minority regimes in Southern Africa, but creates an image that allows us to establish good relations with sub-Saharan Africa, whose political and economic importance grows, even if this requires steps that break fresh ground and do not conform to our foreign policy traditions. ${ }^{1}$

Ambassador Richard Pestalozzi made no secret about which of the two strategies he preferred. Like a number of his colleagues, he advocated a break with the Swiss government's selective interpretation of neutrality in sub-Saharan Africa. Yet, the strategy adopted during the regime changes in Southern Africa and the Horn corresponded to the first - with efforts being made to improve Switzerland's image, but none that can be qualified as ground-breaking. In both regions, Switzerland's foreign policy was mainly driven by the will to improve the country's image in Africa and in the Third World in general. The Swiss government adopted a pragmatic policy that focused on maintaining a political presence and protecting economic interests. Both in Ethiopia and in Mozambique, the Swiss government managed to overcome the new governments' criticism of its foreign policy in sub-Saharan Africa. Bern waited out the controversy surrounding the Ethiopian Emperor's Swiss bank accounts until the Derg's human rights abuses discredited it in the eyes of foreign observers and Ethiopian leaders focused their attention on other problems. After a phase of Swiss-Mozambican tension following FRELIMo's rise to power, Bern quickly found a modus vivendi with Mozambique's new government, despite the latter's radical economic reforms. Humanitarian and development aid played a key role in this regard. By establishing cordial relations with a black Southern African state that promised to be politically stable, Swiss foreign policymakers hoped to dissociate themselves, in the eyes of Afro-Asian leaders, from the past association with the colonial power. Economically speaking, this

1 Letter from Richard Pestalozzi, Swiss ambassador in Kenya, to the DPA, "OAU-Konferenz der Staatschefs in Kampala”, 24.06.1975, p. 4, SFA E2200.185-02\#1987/123\#44*. 
was also less costly than stopping trade with and investments in South Africa and enforcing compliance with the UN sanctions on Rhodesia.

In this context, the new rulers' Soviet ties were of secondary importance. During the decolonisation of Angola and Mozambique, Swiss foreign policymakers concentrated on counterbalancing their relations with South Africa and rarely mentioned the Cold War alliances of FRELIMO and the Angolan liberation movements. The image of Switzerland's neutrality, its stance in the region, and the protection of citizens and economic interests were primordial. In the Horn of Africa, where Swiss material interests were few, the new leaders' ideological orientation more strongly influenced the Swiss government's assessment of the regime changes; these leaders' socialist tendencies and the presence or absence of Soviet and Chinese influence on events were frequently remarked upon in diplomatic reports. Nevertheless, on the whole, Bern treated the four new regimes like any other Third World governments. At a time when the North-South conflict was intensifying and senior decision-makers in Bern recognised the need to improve Switzerland's relations with the Third World, it was the North-South rather than the East-West dimension that determined Switzerland's foreign policy during the regime changes in sub-Saharan Africa.

Most Western and neutral states viewed the events in Southern Africa and the Horn in a similar light. When considering whether or not to recognise the Portuguese colonies, or make a public statement on the November 1974 executions in Ethiopia, Bern's policy decisions were coordinated first, with the neutral governments of Sweden and Austria and second, with the EEC capitals. The increased importance of Western Europe as a frame of reference for Switzerland's foreign policy in sub-Saharan Africa was accompanied by a growing disenchantment with the Ford administration's Africa policy and its ability to influence events on the continent. This would come to a head during the Angolan War. 